Olga Borik

Universitat Autònoma de Barcelona*

\title{
CONSTRAINTS ON THE POSITION AND INTERPRETATION OF BARE SINGULAR INDEFINITES IN RUSSIAN**
}

\section{INTRODUCTION}

It is quite uncontroversial that in languages which do not have overt articles, nominal phrases that appear bare can, in principle, be interpreted in various ways, including as definite, as in (1a) and (1b), as indefinite, as in (1b), or as generic/kind, as in (1c) below:
(1)
a) Poezd prišel.
train.nom arrived
'The/\#A train arrived.'
b) Prišel poezd.
arrived train.nom
'The/A train arrived.'
c) Poezd kak sredstvo peredviženija očen' udoben. train.nom as means transportation.gen very convenient 'The train as a means of transport is very convenient.'

For Russian, this view has always been supported by, for instance, traditional grammars. However, in recent semantic literature, an influential proposal has been made, according to which bare nominals in Russian or Hindi - both languages with no overt articles - can only be interpreted as kind or definite (Dayal 2004), whereas bare singular indefinites in these languages virtually do not exist (at least not in the subject position) or are very restricted. In this paper, I will demonstrate that bare singular indefinites appear quite regularly in Russian, contra Dayal's (2004) proposal. However, the distribution of these nominals is, indeed, subject to certain restrictions, and I will examine in detail the nature of this restriction in the preverbal subject position. One of the previous analyses of this restriction proposed by Geist (2010) relies on the claim that bare singular indefinites are never specifically interpreted. I will argue that this analysis must be modified, since a specific interpretation does, in principle, quite regularly appear with bare singulars in the object position.

\footnotetext{
* olga.borik@gmail.com

** This research has been funded by grants FFI2014-52015-P (awarded by the Spanish Ministerio de Economía y Competitividad) and 2014 SGR 1013 (awarded by the Generalitat de Catalunya). I am very grateful to two anonymous reviewers for their insightful comments. All remaining errors are mine.
} 
In my paper, I will focus only on bare singular nominals. There is much crosslinguistic evidence that supports the view that bare singulars could (and/or should) be treated differently, and separately, from bare plurals. For instance, it is well-known that in English, a language with overt articles, bare plurals can have a generic reading (cf. Carlson 1980). This is also a reading that arises freely and prominently with bare plurals in Russian. Bare singulars, on the other hand, appear to have a relatively restricted distribution in languages with overt articles (cf., for instance, Stvan 1998 for English; Munn \& Schmitt 2005 for Brasilian Portuguese; Doron 2003 for Hebrew; Borthen 2003 for Norwegian; Espinal \& McNally 2011 for Spanish and Catalan; de Swart 2015 for Dutch, English and French) and often receive an incorporation analysis which presupposes that they are not fully referential. In languages without articles, however, bare singulars (henceforth BSgs) possess quite different properties, and since their referential uses are often unmarked, they naturally give rise to a wide range of interpretations in many contexts, as was illustrated in (1) above.

The paper is organised as follows. Section 2 introduces empirical data and gives a brief overview of indefinite uses of BSgs in Russian. Section 3 is devoted to the main theoretical notions that are relevant for the analysis of the facts presented in section 2 , i.e. topicality and specificity. In section 4, I present a proposal for BSgs in subject/ topic position and discuss several consequences of this proposal. Section 5 concludes the paper.

\section{INDEFINITE BARE SINGULARS IN RUSSIAN}

Let me begin this section by illustrating that Russian BSgs can, indeed, have an indefinite reading, contrary to Dayal's (2004) proposal for article-less languages, where indefinite (existential) readings are supposed to be derived from a kind reading. Consider the following Russian example.

\section{(2) Vkazhdom dome igral rebenok. in every house played child.NOM 'A child (a different one) was playing in every house.'}

In a distributive context, like the one given in (2), a nominal phrase cannot be interpreted as either a kind reading, since 'singular' kinds generally cannot facilitate access to individuals (cf. Krifka et al. 1995) and hence cannot distribute, or as a definite reading, since this would lead to an implausible interpretation that there is a unique child playing in every house. Hence, it must be indefinite. Dayal's crucial examples for the absence of an indefinite interpretation with bare singulars in Russian are also based on distributive contexts, ${ }^{1}$ but, as (2) illustrates, distributive sentences do not rule out singular indefinites on a regular basis.

1 Dayal's (2004) examples include BSgs in the preverbal position. Later in the paper, I will argue that BSgs are not readily used as preverbal subjects for other reasons. For some other observations and considerations concerning Dayal's specific examples see, for instance, Bronnikov (2004). 
Another argument in favor of the view that Russian bare singulars do have a proper indefinite interpretation comparable to English $a$-indefinites (i.e., singular nominals with an indefinite determiner) is based on the scope ambiguities that Russian bare singulars regularly exhibit in the object position. ${ }^{2}$ This ambiguity is illustrated in the following example:
(3) Vasja hočet ženit'sja na kinozvezde, Vasja wants marry on movie-star 'Vasja wants to marry a movie star...
a) no ne možet najti podhodjasčuju. want $>$ Indef but not can find suitable ...but cannot find a suitable one.'
b) no my eje esče ne videli. but we her yet not saw ... but we haven't met her yet.'

As shown in (3), a BSg indefinite in an opaque context (i.e., in a complement clause of a propositional attitude verb) can have two readings, which correspond to two different interpretations of the sentence. One reading, illustrated in (3a), is called opaque, in which case the indefinite is interpreted within the scope of the main verb. A transparent reading in (3b) is one in which the indefinite is outside the scope of the main verb. In this latter case, the indefinite is interpreted as referential, or specific, while in (3a) is it a purely quantificational indefinite. The ambiguity illustrated here is a classical test for specific and non-specific (existential) readings of indefinite noun phrases in English and, as (3) illustrates, Russian BSg indefinites are not really different from their English counterparts in allowing both readings.

Finally, let us look at yet another canonical indefinite environment, i.e., existential there sentences. The Russian counterpart of there sentences in English are formed by fronting a locative phrase, as in (4):

\section{(4) V komnate ležal kover. in room lied carpet \\ 'There was a carpet in the room.'}

The example above has a BSg nominal phrase kover 'carpet', which can only be interpreted as an indefinite in the given context.

So far, I have demonstrated that BSgs in Russian freely appear in typical indefinite environments and, moreover, exhibit ambiguities just as bona fide indefinites in English. We can therefore conclude that BSgs in Russian do function as proper full-fledged indefinites.

2 Note that Dayal (2004) does not discuss BSgs in the object position, as in Hindi they can be pseudoincorporated. A pseudo-incorporation analysis for object BSgs in Russian is not really a plausible option since regular accusative objects do not exhibit any properties of pseudo-incorporated nominals. 
There are, however, certain distributional restrictions associated with indefinite BSgs in Russian. These restrictions primarily concern the preverbal subject position. In particular, indefinite subjects in Russian are usually postverbal, whereas BSgs in the preverbal subject position have a tendency to be interpreted as definite. The following example provides an illustration for the above restriction.
(5) V komnate bylo neskol'ko malen'kih detej, mal'čikov $i$ devoček. in room were several small childrenboys and girls 'There were several small children in the room.'
a) \#Devočka podošla ko mne $i$ sprosila... girl.NOM came.up to me and asked... to me came.up girl.NOM and asked... 'A girl came up to me and asked...'
b) Ko mne podošla devočka $i$ sprosila...

In this example, the first sentence in (5) sets a context, which makes sure that there are several boys and girls in the group of children. In this particular context, the continuation in (5a) with an intended indefinite interpretation of devočka 'girl' sounds odd, as the nominal subject has a clear preference for a definite interpretation: the sentence would be perfectly acceptable if there was one girl in the group. If, however, the BSg devočka 'girl' is used postverbally, as in (5b), an indefinite interpretation is entirely adequate.

These restrictions have not gone unnoticed in the literature. In particular, Geist (2010) proposes an analysis which relies on the unavailability of a specific interpretation for indefinite BSg nominals in Russian. The following points comprise the main components of her proposal. First, she assumes that all preverbal subjects in Russian are topics. ${ }^{3}$ With respect to topics, she adopts Reinhart's (1981) proposal, according to which only strongly referential (i.e., specific) indefinites can function as topics. Geist then argues that Russian BSgs cannot have a specific interpretation and that they are therefore excluded from the topic position. This is an explanation offered for the 'oddness' of (5a).

An immediate objection to this proposal is that, in general, BSg indefinites in Russian cannot solely be associated with a non-specific interpretation. This becomes evident if one takes into account examples such as (3) above and the ambiguity associated with BSgs in the object position. ${ }^{4}$ This ambiguity can also be illustrated in a different context, for instance, for an indefinite under negation. Consider the following example:
(6) Vasja byl zloj potomu čto segodja on ne sdal ekzamen. Vasja was angry because that today he not pass exam
'Vasja was angry because today he didn't pass an exam.'

3 A more detailed explanation of the notion of topic is given in the next section.

4 Geist (2010) claims that this ambiguity does not exist. Native speakers that I have consulted, however, support my own judgment and agree that both (3a) and (3b) are fine. 
Just as in (3), a BSg ekzamen 'exam' in (6) can stay in the scope of the negative operator, yielding an interpretation 'it is not the case that Vasja passed an exam today', or scope out of the negative operator and be interpreted specifically, i.e., there was an exam that Vasja didn't pass. Crucially, the data in (3) and (6) indicate that the reason why indefinite BSgs do not easily appear in a preverbal position cannot be associated with a ban on a specific interpretation for indefinite BSgs. Hence, it becomes necessary to seek an alternative explanation. Before offering such an explanation, I will clarify the basic theoretical notions on which I will build my case, namely, topicality and specificity.

\section{THEORETICAL ASSUMPTIONS: THE NOTIONS OF TOPICALITY AND SPECIFICITY}

\subsection{Topics}

Although the concept of topicality has been around for many years and its relevance for linguistics is not a subject of any considerable debate, there are still many ways in which topics are understood. For concreteness, in this paper, the following view on topics is assumed. First of all, only sentential topics and not discourse topics are considered here. A sentential topic is what a sentence is about. This informal characterisation of topicality is known as the one in terms of aboutness and is adopted in Reinhart (1981) and Endriss (2009), among many others. The following example taken from Endriss (2009: 20) can provide an elementary illustration of a topic in a sense adopted here.
(7) a) Yesterday, Clarissa visited Dena.
b) Yesterday, Dena was visited by Clarissa.
c) The telephone rang.

The sentence in (7a) is naturally understood as saying something about Clarissa, whereas (7b) is rather a statement about Dena. In this sense, Clarissa is a topic of (7a) and Dena is a topic of (7b).

From the point of view of information structure, a simple declarative sentence typically consists of two parts, a topic (an entity, in a broad sense) and a comment (saying something about this entity, elaborating on it). However, not all sentences have this structure; some sentences just present a piece of information as a single unit. This distinction is well-known and is usually stated in terms of categorical $v s$. thetic judgments, where only the former have topics, while the latter simply convey all the information in one step, without any division into a topic and a comment. An example of a thetic judgment is given in (7c) above. The behavior of indefinite BSgs in thetic judgements will be of special importance later in the paper.

The examples in (7a) and (7b) illustrate an intimate connection between the grammatical (syntactic) notion of subject and the information structural notion of topic, in the sense that very often subjects are also topics. This does not mean, however, that topic and subject are two equivalent notions: topic is used to describe the information 
structure of a sentence, whereas subject is a purely grammatical category. In passive sentences or in left dislocation structures, topic and subject are clearly dissociated. However, the discussion in this paper is limited to topical subjects only, so for the purposes of this paper it is safe to assume that preverbal subjects in Russian categorical sentences with a neutral word order are by default topics in the sense described above.

Having briefly characterised the notion of topic, I will now turn to another controversial notion in the semantic/pragmatic literature, namely, specificity.

\subsection{Specificity}

In the most general terms, specificity is a notion that concerns different interpretations of indefinite noun phrases. The first discussions of the difference between specific and non- specific indefinites (cf. Karttunen 1968; 1969[1976]) were inspired by the observation that some indefinites can introduce discourse referents, while others do not have this capacity.

In later literature, specificity has been discussed in connection to referentiality (Fodor \& Sag 1982), exceptional scope behavior (Reinhart 1997; Winter 1997), and presuppositionality (Geurts 2002[2010]). Which of these properties is essential to specificity is still a subject of debate, but what seems to emerge from the recent literature on specificity is that referential properties of indefinites are intimately connected to both their discourse status and their scopal properties (cf. von Heusinger 2011 for an overview).

The view on specificity assumed in this paper is based on the referential properties of indefinites. In particular, a specific indefinite has a particular referent, that is, the set of potential referents for an indefinite is limited to few or possibly one entity, whereas a non-specific indefinite does not refer to any entity. This type of ambiguity has already been illustrated above for Russian BSgs in (3) and (6), but let us now look at an example in English (from Dahl 1970):

(8) She wants to marry a man with a big bank account.

a) There is a man with a big bank account that she wants to marry.

b) She wants there to be a man with a big bank account for her to marry.

The example in (8) is ambiguous between the senses in (8a) and (8b). (8a) conveys a specific interpretation of an indefinite, with an existential entailment, i.e., there is a man that she wants to marry. ( $8 \mathrm{~b})$, on the other hand, does not entail that there is a man that she wants to marry and corresponds to a non-specific interpretation, when the indefinite does not refer to any particular man.

In Haspelmath's (1997) typology, specific indefinites can be of two types, known to the speaker and unknown to the speaker, as illustrated in (9) and (10):

(9) Type 1. Specific, known to speaker:

Somebody called while you were away: guess who? 
(10) Type 2. Specific, unknown to the speaker:

I heard something, but I couldn't tell what kind of sound it was.

In both cases, an indefinite pronoun refers to a specific entity (a person or a thing), but in (9) the speaker can identify the referent, whereas in (10), the speaker is ignorant about the identity of the referent.

Finally, note that specific indefinites are different from definite nominal phrases in at least two respects. First, a specific indefinite does not trigger any uniqueness presupposition, i.e. the referent of an indefinite expression is not required to have a unique value shared by the speaker and the hearer. Second, indefinites in general are not anaphoric, i.e., they are not required to refer to a previously mentioned or previously introduced discourse referent (cf. Heim 1982).

In Russian, specificity can be encoded overtly by means of so-called 'indefinite pronouns' (Academy Grammar of Russian 1982), which explicitly mark specificity distinctions:
a) Ja хос̆и koe-čto tebe skasat'.
I want something you tell
'I want to tell you something'/'I have something to tell you.'
b) Maša xočet vyjti zamužza kakogo-to/odnogo izvestnogo bankira. Maša wants marry prep some / one famous banker
'Maša wants to marry a/some/one famous banker.' (there is a specific banker)
c) Maša xočet vyjtizamuž za kakogo-nibud' izvestnogo bankira. Maša wants marry prep some famous banker
'Maša wants to marry a/any famous banker.' (there is no specific banker)

The interpretation of the pronoun koe-čto 'something' in the object position in (11a) is specific and known to the speaker: the speaker definitely knows what exactly s/he is about to say. In (11b), the specificity marker kakogo-to 'some' or odnogo 'one', used with a noun in the object position, indicates that there is a specific famous banker that the girl wants to marry, but in $(11 \mathrm{c})$ the interpretation of the whole nominal phrase with the marker kakogo-nibud' 'some' can only be non-specific. ${ }^{5}$

While indefinites with various specificity markers in Russian have received considerable attention in recent semantic literature (Bylinina \& Testelec 2004; Yanovich 2005; Geist 2008; Ionin 2013; etc.), bare indefinites and their readings have not been investigated in detail. In particular, there is little research dedicated to the question of what kind of interpretation a bare indefinite can convey. I will again contrast the view advocated here with the analysis offered by Geist (2010). In this paper, I argue that BSg indefinites can indeed have a specific interpretation, whereas Geist's (2010) proposal is based on the claim that they cannot. In section 2 (cf. the discussion of examples (3)

5 The type of specificity illustrated in (11) with overt markers is often called 'epistemic' specificity in relevant literature (cf. Ionin 2009). There is an intimate connection between scopal and epistemic specificity, which some accounts (for instance, Kratzer 1998) make explicit. 
and (6)), I have demonstrated that, at least in object position, BSg indefinites exhibit regular scope ambiguities that are observed with bona fide indefinites in English. ${ }^{6}$ This means that a non-specific interpretation is not the only one available for BSg nominals in Russian. In the following section, I present a proposal which takes this into account.

\section{A PROPOSAL AND ITS CONSEQUENCES}

The proposal that I will put forward in this paper is that BSg indefinites in Russian are underspecified with respect to specificity. This characterisation is not reflected in a syntactic or semantic composition of BSg nominals themselves, although the ambiguity conveyed by a BSg is reflected in the logical form of a sentence. Specificity is a pragmatically oriented notion, so it is only reasonable to assume that it has no syntactic representation (unless overtly marked) and specific/non-specific phrases are only distinguished contextually. ${ }^{7}$ Underspecification means that, in principle, BSgs can have both specific and nonspecific interpretations, and that in many contexts where BSgs are found, they will be ambiguous between the two readings. This is exactly what happens in $(3) /(6)$ from section 2 above, where a BSg in the object position can render various (non-)specific readings.

Now I will return to the restriction on BSg indefinites in the subject position. ${ }^{8} \mathrm{Just}$ like it is assumed in Geist (2010), I take preverbal subjects in Russian to be topics. Let me emphasise that this is not a 'topic position' in a syntactic sense, that is, I do not think that Russian preverbal subjects necessarily 'raise' to a specifier of a special topic

6 While it has been argued that there is no direct dependency between wide scope and specificity (cf. Enç 1991), the tendency of specific indefinites to take a wide scope remains, and the interpretation of the object in (3) does not leave any doubt that this nominal expression can have a specific referent.

7 There is an ongoing debate concerning the question of what would be an appropriate syntactic representation for nominal arguments in articleless languages. The proponents of the universal DP hypothesis (e.g., Pereltsvaig 2006) argue for the presence of a null D in languages without articles, whereas those who advocate the parametrised DP hypothesis (e.g., Bošković 2008) argue for a bare NP structure for nominal phrases in languages like Russian. There are, however, strong reasons to believe that there are nominal projections of different 'sizes' both in languages with and without articles and this syntactic difference is reflected in the interpretation of nominals. This view is advocated in Pereltsvaig (2006) and I support it, although I do not have the possibility of defending my position here. Based on this view, however, I assume that indefinite nominal arguments are represented as DPs with an underspecified D (cf. Ramchand \& Svenonius 2008), so that both an indefinite and a definite interpretation can be derived with the same null element.

8 By now the reader might wonder if something is amiss in the argument since I shift freely from BSgs in object position to those that appear in subject position. The point I am making, however, remains valid: if BSgs cannot have a specific interpretation, it should be a property of a $\mathrm{BSg}$ itself, and not a property of the environment in which it appears. What I demonstrate is that the inavailability of a (non-)specific indefinite reading cannot be attributed to the structural properties of a nominal argument itself.

In relation to the subject/object asymmetry, a reviewer asked whether or not it is possible to tropicalise an object argument in Russian. The answer is yes, and topicalised objects are actually interpreted definitely (cf. Erteschik-Shir 2013), as in (i): 
projection. I simply assume that preverbal subjects are syntactically subjects (that is, they are found in a 'standard' subject position, like a SpecTP, for instance), but from the perspective of the information structure, they are topics, i.e. they name an entity about which the rest of the sentence says something. Sentential topics are not obligatory, whereas subjects (at least if we assume EPP) are structurally indispensable. Furthermore, I adopt the position defended in Reinhart (1981) that only specific indefinites can be topical.

The combination of these assumptions leads to the following picture with respect to BSgs in Russian. BSgs, as I have suggested above, are underspecified with respect to specificity. This means, under the definition of specificity adopted here, that these expressions do not necessarily have a referent, but that it can be established if additional information is provided. This information can be sentential or, possibly, contextual, but I will not consider contextual factors in a broad sense here. The point is that BSgs cannot function as sentential topics unless they are disambiguated and established as referring specifically.

Let us now go back to the context for which it was first shown that BSgs cannot freely occur as topics. The context was given in (5) in section 2 and is repeated below:
(12) V komnate bylo neskol'ko malen'kih detej, mal'čikov $i$ devoček. in room were several small children boys and girls 'There were several small children in the room.'
a) \#Devočka podošla ko mne $i \quad$ sprosila... girl came.up to me and asked...
b) Ko mne podošla devočka $i$ sprosila... to me came.up girl.nom. and asked... 'A girl came up to me and asked...'

Once again, an explanation that I propose for the oddness of (12a) is based on the claim that BSgs are underspecified with respect to specificity and the subject of (12a) should be interpreted as a topic, i.e. as having a specific referent. There are at least two

(i) (a professor, talking about his first lecture for a big audience)

Devušku ja zapomnil očen' xorosho: ona zapisyvala každyj primer.

girl.ACC I.NOM remembered very well: she copied every example

'The/*A (certain) girl I remember very well: she copied every example.'

The sentence in (i) presupposes that there was only one girl in the whole audience. Thus, a specific indefinite interpretation is impossible for the topicalised bare object in (i); a specificity marker is obligatorily used to appropriately render such an interpretation, as in (ii):

(ii) (a professor, talking about his first lecture for a big audience)

Odnu devušku ja zapomnil očen' xorosho: ona zapisyvala každyj primer.

one girl.ACC I.NOM remembered very well: she copied every example

'There was a girl that I remember very well: she copied every example.'

Thus, topicalised objects seem to be subject to the same type of restrictions as preverbal subjects ( $c f$. the discussion of (5)). 
possible ways to make the subject of (12a) specific: either by adding an overt specificity marker, or by enriching the descriptive content of the nominal phrase (cf. also Geist 2010 for this observation) to narrow down a set of possible referents. Both strategies lead to a full acceptance of a modified sentence in the same context, as demonstrated in the following two examples:

(13) Odna/kakaja-to devočka podošla ko mne $i$ sprosila... one/some(spec.) girl came.up to me and asked...

'One/some girl came up to me and asked...'

(14) Devočka so slomannoj kukloj $v$ ruke podošla ko mne $i \quad$ sprosila... girl with broken doll in hand came.up to me and asked... 'A girl with the broken doll in her hand came up to me and asked...'

To check some of the further consequences of the proposal, we will now examine the behaviour of indefinite BSgs in two other types of constructions, namely, as subjects of individual level (i-level) predicates and as subjects of thetic jugements. The main reason for choosing these two constructions is that they have a (relatively) clear status with respect to the topic-comment structure. In particular, the subjects of i-level predicates have been argued to always be topics (cf. Chierchia 1995), whereas thetic jugements by definition lack topics (Ladusaw 1994). Therefore, there are two opposite expectations with respect to BSg indefinites in these constructions: they should be ruled out in combination with i-level predicates and available without any restrictions in thetic sentences.

First, I-level predicates should be considered. The following example from English can be used to illustrate that indefinite subjects of i-level predicates must be strongly referential:

\section{(15) A fireman is altruistic.}

In this sentence, the indefinite subject can only have a generic or a specific (socalled 'strong' referential reading), but cannot refer to an arbitrary, non-specific fireman. If i-level predicates in Russian impose the same restrictions on the interpretation of their indefinite subjects (and there should be no a priori reason why they would not), one expects BSg indefinites to be 'difficult' in these contexts, as they are in the topic position of other categorical sentences. Once again, specificity markers should help to turn an underspecified BSg into a fully referential indefinite, which will be acceptable as a subject of an i-level predicate. Consider now the examples:

(16) a) Student byl smyšlenyj.
student was smart
'The/\#A student was smart.'
b) Odin student byl smyšlenyj.
one student was smart
'A (specific) student was smart.'


As expected, a BSg in (16a) cannot really be interpreted as indefinite. The reason sould presumably be the same one that rules out topic BSgs in episodic sentences: their underspecification with respect to specificity, and their inability to have a particular referent without any additional means. Once an overt specificity marker odin (one) is used in a modified version of the sentence, as in (16b), the indefinite nominal becomes acceptable.

Consider now thetic judgments. By definition, thetic judgments are topicless, so one's expectation is that there is no restriction on the interpretation of indefinite nominal phrases in thetic judgments and, in particular, no restriction on BSgs in this type of sentences. These expectations are indeed supported by the data. If one considers a sentence with a BSg subject that is used in some typical context for a thetic judgment, then, indeed, any restrictions on the interpretation of BSgs seem to disappear. This is illustrated in (17).

(17) Situation: All of a sudden, A and B see a big crowd gathered around an ambulance and a police car on a busy street.
A: Čto slučilos', kak ty dumaeš? what happened how you think 'What do you think happened?' car probably someone hit 'Probably a car hit somebody.'
B: Mašina, navernoe, kogo-nibud' sbila.

In this example, a context is set that makes it highly implausible for a BSg in subject position in the B-answer to be interpreted as anything but an indefinite. Note that this indefinite can be both specific and non-specific, but in the absence of any additional (linguistic or extra-linguistic) information, the subject - mašina, or 'car' - tends to be interpreted as non-specific. A specific interpretation seems to be difficult to obtain without any specificity markers. ${ }^{9}$

To conclude this section, I will briefly address the question of motivating a connection between specificity and topics. The link between the two notions becomes more apparent once certain additional assumptions about topics are made. In particular, there is a view in relevant literature that considers a topic to be not a linguistic entity (i.e., a phrase) in and of itself, but rather a denotation of this entity (Dahl 1974; Portner and Yabushita 1998; Endriss 2009). If this hypothesis is adopted, it naturally follows that only referential expressions can serve as topics, since non-referential indefinites do not denote entities. In other words, if a linguistic expression is of the type that does not or cannot have a particular referent, this expression cannot serve as a topic. If BSg indefinites are underspecified, the referent of a BSg indefinite in Russian cannot be unambiguously

9 The reasons why the pattern is such remain to be understood. One speculation is that a specific reading is difficult to obtain for a BSg precisely because specificity is one of the very few nominal categories that can be marked in Russian. A pragmatic principle could be responsible for a preference for specificity markers in those cases where they can be appropriately used. 
established and consequently these expressions cannot be freely used in the topic position. In other words, the topic position does not tolerate underspecification.

\section{CONCLUSION}

In this paper, I have demonstrated that an indefinite interpretation is, indeed, available for BSgs in Russian (contra Dayal 2004) and that Russian indefinite BSgs are comparable to their canonical English counterparts with an indefinite article. In particular, BSgs can be interpreted both specifically and non-specifically, and can take a wide scope with respect to other scopal elements in a sentence. On the other hand, BSg indefinites do not freely appear in preverbal subject/topic position. I have argued that this is because a specific interpretation, or, in other words, a referential reading, required for a nominal in this position cannot be unambiguously established with BSgs, at least not without any additional sentential specification. Note that in the object position, where the information structure does not pose any special requirements, a BSg can remain underspecified, which results in two available interpretations of a sentence: one in which a BSg object is interpreted non-specifically, and another in which a BSg object has a specific reading. ${ }^{10}$

\section{References}

BOŠKOVIĆ, Željko (2008) "What Will You Have, DP or NP?" In: E. Elfner/M. Walkow (eds), Proceedings of NELS 37. Amherst, MA: GLSA, 101-114.

BORTHEN, Kaia (2003) Norwegian Bare Singulars. PhD dissertation. Trondheim: NTNU.

BRONNIKOV, George (2004) A Critique of Dayal. Ms. University of Texas at Austin. BYLININA, Lisa/Yakov G. TESTELEC (2004) "Sluicing-Based Indefinites in Russian." In: S. Franks at al. (eds), Formal Approaches to Slavic Linguistics 13: The South Carolina Meeting. Ann Arbor, MI: Michigan Slavic Publications, 355-365.

CARLSON, Greg (1980) References to Kinds in English. New York: Garland CHIERCHIA, Gennaro (1995) "Individual Level Predicates as Inherent Generics." In: G. Carlson/F. Pelletier (eds), The Generic Book. Chicago: Chicago University Press, 176-223.

DAHL, Östen (1970) “Some Notes on Indefinites.” Language 46/1, 33-41.

DAHL, Östen (1974) “Topic-Comment Structure Revisited.” In: Ö. Dahl (ed.), Topic and Comment, Contextual Boundedness and Focus, Hamburg: Helmut Buske, 1-24.

DAYAL, Veneeta (2004) "Number Marking and Indefiniteness in Kind Terms." Linguistics and Philosophy 27, 393-450.

10 There are some other indications that subject position imposes more restrictions than object position. For instance, the non-specific marker kakoj-nibud' 'some' (cf. ex. (11c) above) cannot easily appear modifying preverbal subjects. Whether the restrictions on BSgs have anything to do with the restrictions on -nibud' markers remains to be established. 
DORON, Edit (2003) "Bare Singular Reference to Kinds.” In: R. B. Young/Yuping Zhou (eds), Proceedings of SALT 13. Seattle: University of Washington, 73-90.

ENÇ, Murvet (1991) “The Semantics of Specificity.” Linguistic Inquiry 22/1, 1-25.

ENDRISS, Cornelia (2009) Quantificational Topics. A Scopal Treatment of Exceptional Wide Scope Phenomena. Dordrecht: Springer.

ERTESCHIK-SHIR, Nomi (2013) "Information Structure and (In)definiteness." In: P. Cabredo Hofherr/A. Zribi Hertz (eds), Crosslinguistic Studies on Noun Phrase Structure and Reference. Leiden: Brill, 23-51.

ESPINAL, M. Teresa/Louise MCNALLY (2011) "Bare Nominals and Incorporating Verbs in Catalan and Spanish." Journal of Linguistics 47, 87-128.

FODOR, Janet and Ivan SAG (1982) "Referential and Quantificational Indefinites." Linguistics and Philosophy 5, 355-398.

GEIST, Ljudmila (2008) "Specificity as Referential Anchoring: Evidence from Russian." In: A. Grønn (ed.), Proceedings of Sinn und Bedeutung 12. Oslo: ILOS, 151-164.

GEIST, Ljudmila (2010) "Bare Singular NPs in Argument Positions: Restrictions on Indefiniteness." International Review of Pragmatics 2, 191-227.

GEURTS, Bart (2002[2010]) “Specific Indefinites, Presupposition, and Scope.” In: R. Bäuerle/U. Reyle/T. E. Zimmermann (eds), Presupposition and Discourse. Bingley: Emerald, 125-158.

HASPELMATH, Martin (1997) Indefinite Pronouns. Oxford: Clarendon Press.

HEIM, Irene (1982) The Semantics of Definite and Indefinite Noun Phrases. PhD Dissertation. Amherst: University of Massachusetts.

von HEUSINGER, Klaus (2011) “Specificity.” In: K. von Heusinger/C. Maienborng/P. Portner (eds), Semantics: An International Handbook of Natural Language Meaning. Vol 2. Berlin: de Gruyter, 1024-1057.

IONIN, Tania (2009). "Specificity.” In: L. Cummings (ed.), The Pragmatics Encyclopedia. New York: Routledge.

IONIN, Tania (2013) "Pragmatic Variation among Specificity Markers." In: S. Hinterwimmer/C. Ebert (eds), Different Kinds of Specificity Across Languages. Dordrecht: Springer, 75-103.

KARTTUNEN, Lauri (1968) "What Do Referential Indices Refer To?" Technical Report P38543, RAND Corporation Report. Santa Monica, California.

KARTTUNEN, Lauri (1969[1976]) "Discourse Referents." In: Proceedings of the 1969 Conference on Computational Linguistics. Sång-Säby, Sweden, 1-38. http:// portal.acm.org/citation.cfm?id=990403.990490). [Reprinted in: J. McCawley (ed.), Syntax and Semantics 7: Notes from the Linguistic Underground. New York: Academic Press, 1976, 363-385.]

KRIFKA, Manfred/Francis J. PELLETIER/Greg CARLSON/Alice ter MEULEN/Godehard LINK/Gennaro CHIERCHIA (1995) "Introduction." In: G. Carlson/F. Pelletier (eds), The Generic Book. Chicago: The University of Chicago Press, 1-124.

KRATZER, Angelika (1998) "Scope or Pseudoscope? Are there Wide-Scope Indefinites?” In: S. Rothstein (ed.), Events and Grammar. Dordrecht: Kluwer, 163-196. 
LADUSAW, William (1994) "Thetic and Categorical, Stage and Individual, Weak and Strong." In: M. Harvey/L. Santelmann (eds), Proceedings of SALT IV. Ithaca, NY: Cornell U. DMLL, 220-229.

MUNN, Alan/Cristina SCHMITT (2005) "Number and Indefinites." Lingua 115/6, 821-855.

PERELTSVAIG, Asya (2006) "Small Nominals." Natural Language and Linguistic Theory 24, 433-500.

PORTNER, Paul/Katsuhiko YABUSHITA (1998) "The Semantics and Pragmatics of Topic Phrases." Linguistics \& Philosophy 21, 117-157.

RAMCHAND, Gillian/Peter SVENONIUS (2008) "Mapping a parochial lexicon onto a Universal Semantics." In: M. Teresa Biberauer (ed.), The Limits of Syntactic Variation. Amsterdam: John Benjamins, 219-245.

REINHART, Tanya (1981) "Pragmatics and Linguistics. An Analysis of Sentence Topics." Philosophica 27, 53-94.

REINHART, Tanya (1997) "Quantifier Scope: How Labour is divided between QR and Choice Functions." Linguistics \& Philosophy 20, 335-397.

STVAN, Laurel Smith (1998) The Semantics and Pragmatics of Bare Singular Noun Phrases. Ph.D. thesis. Chicago: Evanston.

de SWART, Henriette (2015) "Constructions with and without Articles." In: O. Borik/B. Gehrke (eds), The Syntax and Semantics of Pseudo-Incorporation. Leiden: Brill. 126-156.

ŠVEDOVA, Natalija Ju. (ed.), (1982) Russkaja grammatika. Moscow: Nauka.

WINTER, Yoad (1997) "Choice Functions and the Scopal Semantics of Indefinites." Linguistics \& Philosophy 20, 399-467.

YANOVICH, Igor (2005) "Choice-Functional Series of Indefinites and Hamblin Semantics." In: E. Georgala/J. Howell (eds), Proceedings of Semantics and Linguistic Theory 15. Ithaca, NY: Cornell University, 309-326. 


\section{Summary \\ CONSTRAINTS ON THE POSITION AND INTERPRETATION \\ OF BARE SINGULAR INDEFINITES IN RUSSIAN}

In this paper, I discuss the distribution of bare singular indefinite nominals in Russian. I argue that these nominal phrases are full-fledged indefinites and can have both specific and non-specific indefinite interpretations. However, their appearance in the preverbal subject position is not common. I argue in this paper that this restriction exists because a specific interpretation, or, in other words, a referential reading, required for this position cannot be unambiguously established with BSgs without any additional sentential specification. Additionally, I discuss some consequences of my proposal, such as BSg subjects of individual-level predicates, and BSg subjects in thetic judgments.

Keywords: indefinite, Russian, specificity, topic

Povzetek

OMEJITVE POZICIJE TER INTERPRETACIJE GOLIH SAMOSTALNIKOV V EDNINSKI NEDOLOČNI OBLIKI V RUŠČINI

Članek obravnava distribucijo golih samostalnikov v edninski nedoločni obliki v ruščini. Zagovarja trditev, da so te samostalniške zveze polno razvite nedoločniške oblike, ki lahko prejmejo tako specifično kot nespecifično nedoločno interpretacijo. Vseeno pa se redko pojavljajo pred glagolom v položaju osebka. V članku je ta omejitev analizirana kot posledica dejstva, da specifično oz. nanosniško branje, ki ga zahteva ta položaj, pri golih samostalnikih v edninski nedoločni obliki ne more biti nedvoumno vzpostavljeno brez dodatne stavčne specifikacije. Članek obravnava tudi nekaj posledic, ki sledijo iz predlagane analize.

Ključne besede: nedoločna oblika, samostalnik, ruščina, specifičnost, izhodišče 